\title{
pH3 Antibody Staining Protocol for Zebrafish
}

\author{
Lili Jing*
}

Department of Cell and Molecular Biology, University of Pennsylvania, Philadelphia, USA

*For correspondence: lilijingen@gmail.com

[Abstract] Phosphorylation of histone $\mathrm{H} 3$ is tightly correlated with chromosome condensation during both mitosis and meiosis. Staining for phosphor histone $\mathrm{H} 3$ is a good indicator for the proliferation of cells of interest. This protocol provides a method to stain $\mathrm{p}$ histone $\mathrm{H} 3$ in zebrafish embryos.

\section{Materials and Reagents}

1. PFA

2. Phosphate buffered saline (PBS)

3. Acetone

4. Alcohol

5. PBS-Tween 20

6. $\mathrm{H}_{2} \mathrm{O}_{2}$

7. DMSO

8. Maleic Acid

9. p-Histone $\mathrm{H} 3$ antibody, $200 \mu \mathrm{g} / \mathrm{ml}$ (Cell Signaling Technology, catalog number: 9701 )

10. Blocking regent (Roche Diagnostics, catalog number: 1096176)

11. Diaminobenzidine (DAB) (Sigma-Aldrich, catalog number: D-5905)

12. Peroxidase-conjugated Affinity Goat anti rabbit Ig (Promega Corporation, catalog number: W4011)

13. Block solution (see Recipes)

14. DAB solution (see Recipes)

15. 10x MAB buffer (see Recipes)

\section{Equipment}

1. Shaker

2. Parafilm

3. Cold-room 


\section{Procedure}

\section{A. DAY 1:}

1. Fix embryos in $4 \%$ PFA. Remove PFA before the staining.

2. $2 x$ PBS ( $\sim 5 \mathrm{~min})$ rinses to remove remaining PFA. Incubate samples in $-20{ }^{\circ} \mathrm{C}$ Acetone for $7 \mathrm{~min}$.

3. Dump acetone (alcohol/acetone waste) and wash samples in water.

4. Do $2 \times 5$ min washes with PBST. Place the embryos on shaker at $\sim 40 \mathrm{rpm}$ for more effective washing.

5. While samples are washing, prepare block solution. Use $500 \mu \mathrm{l} \sim 1 \mathrm{ml} / \mathrm{sample}$.

6. After 2nd wash, place samples into Block for at least $30 \mathrm{~min}$ on the shaker (nonspecific blocking step).

7. Dilute primary antibody (p-Histone $\mathrm{H} 3$ antibody, $200 \mu \mathrm{g} / \mathrm{ml}$ ) $1 / 750$ into the Block. (Note: Primary antibody can be reused up to 2 times within the same week!)

8. Shake samples $\mathrm{O} / \mathrm{N}$ in the cold-room (at $4{ }^{\circ} \mathrm{C}$ ). Seal tube with parafilm prevent evaporation of liquid.

\section{B. DAY 2:}

1. Do $4 \times 5$ min washes with PBST.

2. Dilute secondary antibody (Peroxidase-conjugated Affinity Goat anti rabbit Ig) at $1 / 300$ into fresh block.

3. Shake secondary antibody for $2 \mathrm{~h}$ at room temperature (RT).

4. Remove and discard secondary antibody solution. Do 4 × 15 min washes with PBST.

5. While samples are washing, prepare DAB solution.

Note: Combine PBS and two tablets in a $50 \mathrm{ml}$ conical vial. Wrap the mixture in tin foil, as the sample is light sensitive.

6. Add $24 \mu \mathrm{l}$ hydrogen peroxide (30\%) to DAB mixture (this activates the DAB).

7. Vortex solution, then transfer to samples $\left(12 \mu \mathrm{l} \mathrm{H}_{2} \mathrm{O}_{2}\right.$ for each tablet=15 $\mathrm{ml}$ of DAB mixture).

8. Remove and discard DAB (special waste stream).

9. Check if embryos have visible staining.

10. Wash samples in PBST to remove residual DAB.

11. Place samples into PFA for storage.

Note: Once samples are placed into PFA, samples must undergo acetone treatment if restained. 


\section{$\underline{\text { Recipes }}$}

1. Block solution: to make $100 \mathrm{ml}$ of Block

$70 \mathrm{ml}$ of PBST

$20 \mathrm{ml}$ of block reagent (10\% in Maleic acid buffer, MAB)

$10 \mathrm{ml}$ of lamb serum

$1 \mathrm{ml}$ of DMSO

2. $10 \times \mathrm{MAB}$ buffer $(1 \mathrm{~L})$

Maleic acid: $116.1 \mathrm{~g}$

$\mathrm{NaCl}: 87.66 \mathrm{~g}$

Water to about $800 \mathrm{ml}$

3. Start adding $\mathrm{NaOH}$ pellets while stirring the solution. The ppt will not solubilize until the $\mathrm{pH}$ reaches about 5.5 to 6.0. At this point, start adding the pellets VERY carefully as it is easy for the $\mathrm{pH}$ to overshoot. When the $\mathrm{pH}$ reaches 7.5 , top up with water to the correct volume and then autoclave if desired.

4. DAB solution (developer)

$30 \mathrm{ml}$ of DAB

$30 \mathrm{ml}$ PBS

2 DAB tablets (toxic)

\section{Acknowledgments}

This protocol was modified from the original protocol created and developed in the Len Zon lab at Boston Children's Hospital and this work was supported by NIH grant R01 HL04880-21. 